\title{
The Beautiful Mrs Seidenman (Początek)
}

\author{
Author: Andrzej Szczypiorski
}

First Published: 1986

Translations: German (Die schöne Frau Seidenman, 1988); French (La jolie Madame Seidenman, 1988); Italian (La Bella Signora Seidenman, 1988); Danish (Den smukke fru Seidenmaneller Begyndelsen, 1989); Dutch (De mooie mevrouw Seidenman, 1989); English (The Beautiful Mrs Seidenman, 1989); Norwegian (Begynnelsen, 1990); Swedish (Den vackra fru Seidenman, 1990); Hungarian (A szép Seidenmanné, 1991); Czech (Počátek, 1993); Finnish (Alku, 1994); Slovenian (Začetek, 1996); Spanish (La bella señora Seidenman: el comienzo, 2002).

About the Author: Szczypiorski (1928-2000) was born to a well-educated family. His father organised an underground university during World War II and he was a member of the People's Army (Armia Ludowa). For his participation in the Warsaw Uprising in 1944 he was arrested and detained in Sachsenhausen concentration camp. After the war, he worked for local newspapers and Polish Radio. His first literary productions were released under the pseudonym Maurice St Andrew in Życie Literackie in 1952. After joining the Polish Communist Party in 1956, he worked as cultural attaché in the Polish embassy in Copenhagen and continued to publish feuilletons in numerous Polish magazines. He resigned from his membership in the party after the political crisis in 1968. He was forbidden to appear in public in 1969 and his texts were banned from 1972, but he continued writing in the literary underground (drugi obieg), wrote anonymously for opposition newspapers, and started working for the Polish exile monthly Kultura in Paris (Worsowicz, 2003). After his death, the right-wing media in particular discussed the evidence for Szczypiorski being a secret agent for the Polish Security Service in the 1940s (Kruczek, 2007).

Further Important Publication: Msza za miasto Arras (1971, A Mass for Arras; novel).

\section{Content and Interpretation}

The plot is situated in occupied Warsaw where 19-year-old Paweł Kryński tries to earn money as an assistant to an art trader. Apparently, he is in love with two women, one of whom is the Jewish widow Irma Seidenman. The Jew Bronek Blutman reveals her new assumed identity as a Catholic Pole, Maria Magdalena Gostomska. In consequence, she is arrested and sent to the Gestapo headquarters at Szuch Avenue. She manages to inform her neighbour, Adam Korda, who later turns out to be her secret admirer, about the arrest. Together with Johann Müller, a Polish-speaking German born in Lodz, they convince the head of the Gestapo, Stuckler, to release Mrs Seidenman. Meanwhile, Paweł Kryński and Henryk Fichtelbaum, the son of a Jewish

Ә Open Access. (C) 2021 Elisa-Maria Hiemer, published by De Gruyter. (cc) BY-NC-ND This work is licensed under a Creative Commons Attribution-NonCommercial-NoDerivatives 4.0 License. https://doi.org/10.1515/9783110671056-006 
lawyer, become friends. When Henryk flees from the ghetto, Paweł offers him shelter. After some time in hiding, Henryk decides to go back to the ghetto to face his fate. Unlike his sister Joasia, he does not survive the war. Joasia is carried out of the ghetto by Wiktor Suchowiak. This action is threatened by a brawl between Wiktor and a Polish shmaltsovnik (a person blackmailing Jews) called Beautiful Lolo. Once Wiktor has successfully delivered her to a Polish nun, Joasia assumes a new identity as a Catholic orphan. The main plot is frequently interrupted by glimpses into the future lives of the characters. Joasia becomes Marysia Wiewiórka, leaves Poland after 1968, and settles in Israel. After the war, Irma Seidenman becomes a high functionary in the Polish State Service, ironically located in the Szucha Avenue building, and then emigrates to France, although Paweł keeps begging her to stay. Beautiful Lolo and Wiktor Suchowiak meet again years later in a building materials factory. Lolo is the factory manager and pays Suchowiak hush money to keep quiet about his behaviour during World War II. In stylistic terms, the novel is founded on a binary model of characters mainly presented through the narrator's point of view. Every positive character seems to have its antagonist (e.g. the "good German" Müller vs the "bad German" Stuckler, $\rightarrow$ The Pianist, $\rightarrow$ The Menorah, and $\rightarrow$ Death is Called Engelchen) or diametric opposite in terms of religion or education. Whereas the narrator's voice often mixes philosophic thoughts and judgement, the dialogues between characters serve to underline the narrator's opinion, which leads to a certain degree of predictability.

\section{Main Topics and Problems}

Polish literary critics were particularly sensitive to the contrast between the undoubtable importance of the topics raised in the plot and the platitudes expressed by the narrator and characters. Furthermore, numerous critics mention the problem of trivialisation of the Polish fate under German occupation. Especially the character of Pawel reflects on the role of the Polish nation:

"What are you thinking about?” Gruszecki asked silently. "About my internment,” Paweł answered. "A short, trivial story. But in a spiritual manner worse than the concentration camp. When I looked at the Masovian and the Lesser Polish faces of boys in police camouflage jackets, I fell into the abyss.” (Szczypiorski, 2004, p. 231)

The omniscient narrator appears in the role of a moral instance, often accompanied by an ironic subtext: "whereas for the Poles there was no doubt that they were under special care of the Holy Mother, while Germans were crusaders, and Russians slave souls" (p. 253). In contrast to the generalised negative judgement about the Polish nation, the narrator stresses individual character features of the German figures, e. g. the Gestapo officer Stuckler. In the narrator's opinion, "Stuckler wasn't born as a killer without consciousness, because killers without consciousness aren't born anytime or anywhere. And nobody started his or her criminal acts by setting fire to the world or by mass executions.” (p. 252). Szczypiorski’s novel succeeded especially on 
the German book market. His approach to presenting history was considered as a way of rethinking stereotypes and common convictions. As a central figure of German-Polish reconciliation (Jaranowski, 1992, p. 8), Szczypiorski was awarded the Order Pour le Mérite by the German Federal President in 1995. Besides the controversial historical topics addressed in the book, the meaning and the influence of the title is worth considering. It is obvious that the literal translation, The Beginning was preferred in Eastern European countries, whereas other translations mainly followed the German edition. This causes remarkable differences in interpretation. Critics of The Beautiful Mrs Seidenman stressed the love story around the supposedly main characters of Irma and Pawel, which of course allowed them to overlook the controversial historical allusions and discussions in the text. (Hiemer, 2012, pp. 136ff.) Deprived of its original title, the story also loses its often ironic subtext and the historical dimension the narrator wants to point to. Obviously, after World War II a new beginning was possible, but Poland could not take advantage of that, as one totalitarianism succeeded another.

\section{Cited Works}

Hiemer, E.-M. (2012). Andrzej Szczypiorskis Początek: Zum Einfluss von Geschichtsbildern auf die deutsche und polnische Rezeption. In: R. Ibler, ed., Ausgewählte Probleme der polnischen und tschechischen Holocaustliteratur und -kultur. Materialien des internationalen Workshops in Gießen, 27.-28. Mai 2010. München, Berlin: ibidem, pp. 119140. Jaranowski, M. (1992). Fenomen Szczypiorskiego. Życie Warszawy, 23.06., pp. 89. Kruczek, A. (2007). Donosiciel, agent wpływu, autorytet. Nasz Dziennik, 17./18.2., available at: http://www.naszdziennik.pl/index.php?typ=my\&dat=20070217\&id=my09.txt [Accessed: 10.05.2012]. Szczypiorski, A. (2004). Początek. Poznań: Sens. Worsowicz, M. (2003): Andrzej Szczypiorski - Z biografii pisarza i publicysty. Acta Universitatis Lodziensis. Folia Litteraria Polonica 34(6), pp. 291-300.

\section{Further References}

Biernacki, A. (1989). O „Początku“ czyli „Pięknej pani Seidenman“ za granicą (... w Ameryce i Francji). Literatura na Świecie, 5/6, pp. 622-624. Kijowska, M. (2003). Der letzte Gerechte. Berlin. Aufbau-Verlag. Levine, M. G. (1997). Nostalgia for Apocalypse: Andrzej Szczypiorski’s The Beautiful Mrs. Seidenman. In: R. A. Prierand, G. Gillespie, eds., Narrative Ironies. Amsterdam: Rodopi, pp. 91-105. Piękoś, M. (2006). Recepcja powieści Andrzeja Szczypiorskiego „Die schöne Frau Seidenman“ w Niemczech. Orbis Linguarum, 30, pp. 217-225. Uffelmann, D. (2013). Deutscher Kommerz mit polnischer Literatur über jüdische Themen. Maria Nurowska, Andrzej Szczypiorski und Dariusz Muszer. In: K. Smola, ed., Osteuropäisch-jüdische Literaturen im 20. und 21. Jahrhundert. Identität und Poetik = Eastern European Jewish Literature of the 20th and 21st Centuries: Identity and Poetics. München: Sagner, pp. 298-319. Zielińska, M. (2015). Wendepunkte, Brüche und Kontinuitäten im polnischen kulturellen Gedächtnis 1944/ 1945-2011 und die Funktion der Narrative über „Deutsche und Polen“ im Krieg. In: 
C. Gansel, M. Wolting, eds., Deutschland- und Polenbilder in der Literatur nach 1989. Göttingen: Vandenhoeck \& Ruprecht, pp. 177-197.

EMH 